\title{
Suicidal atferd som kommunikasjonshandling: betydningen av kjønn og kultur
}

Ved H eidi H jelmeland og Birthe Loa Knizek

\begin{abstract}
I denne artikkelen vil vi diskutere det kommunikative aspektet ved villet egenskade ved å ta utgangspunkt i intensjonaliteten ved slike handlinger. Kommunikasjonsteoretiske modeller kan vaere nyttige hjelpemidler i behandling av suicidale. Det ser ikke ut til å vaere saerlige kjønnsforskjeller når det gjelder hva som kommuniseres ved hjelp av suicidale handlinger, ei heller kulturelle forskjeller, i hvert fall ikke innenfor Europa.
\end{abstract}

Et aspekt ved suicidale handlinger som det hittil har vært fokusert svært lite på, i hvert fall forskningsmessig, er det kommunikative aspektet ved slike handlinger. Dette aspektet er for eksempel ikke nevnt i den nyeste, og ellers omfattende, norske boken innenfor feltet: Selvmord - et personlig og samfunnsmessig problem

(Retterstøl et al. 2002).

$\mathrm{N}$ år man ser på suicidale handlinger som kommunikasjon, blir to spørsmål sentrale, nemlig hvorvidt det er snakk om kjønnsforskjeller og/eller kulturelle forskjeller

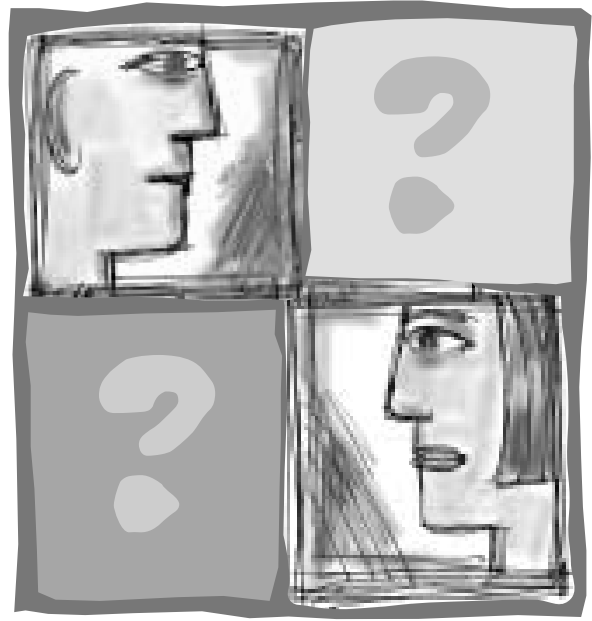

i denne måten å kommunisere på, slik som det er i verbal kommunikasjon for eksempel. Begge disse spørsmålene kommer vi tilbake til i slutten av artikkelen, men først gjennomgås temaet generelt.

$\mathrm{N}$ å er ikke dette med suicidal atferd som kommunikasjonshandling på noen måte nye tanker. A llerede for over førti år siden omtalte Farberow og Shneidman (1961) det kommunikative aspektet ved suicidale handlinger som ikke ender med døden. Siden har det sporadisk vært nevnt av flere forfattere opp gjennom tidene, men det har altså ikke fenget aktørene innenfor forskningsfeltet her i N orge i særlig grad. Her i landet kan det synes som om man er mer opptatt av å diagnos tisere og medisinere de som skader seg selv med vilje, fremfor å forsøke å finne svar på spørsmål som hvorfor de gjorde det, al tså hva de ønsket å oppnå med å skade seg selv. Depresjon er for eksempel karakteristisk for mange av de som tar sitt eget liv og for noen av de som skader seg selv med vilje uten å dø av det, men de aller fleste deprimerte tar verken livet av seg eller skader seg selv. Vi trenger derfor noe mer enn diagnostisering og medisinering når det gjelder å forebygge selvmord.

I vitenskapsteorien har det også vært pekt på (bl.a. av G ilje og G rimen, 1993) at man innenfor psykologisk forskning bør fokusere mer på teleologiske (intensjonelle) forklaringer fremfor årsaksforklaringer. Dette betyr at vi heller bør se på hva folk ønsker å oppnå med sine selvdestruktive handlinger fremfor å lete etter de bakenforliggende årsaker. D et vil si å se på intensjonen(e) med handlingen, og det er her dette med kommunikasjonsaspektet ved slike handlinger kommer inn. $\mathrm{H}$ va er det som kommuniseres på denne måten? Dette betyr at også kontekst- og prosessperspektivet må trekkes inn. Tidligere forskning har også vist at intensjoner med suicidale handlinger som ikke ender med døden, har relativt høy prediktiv verdi for senere selvmord (bl.a. H jelmeland 1996). Kunnskap om og forståelse av hvilke intensjoner som er involvert i suicidale handlinger, er derfor viktig når det gjelder behandling og oppføl ging av suicidale personer, for eksempel for à forhindre at den selvdestruktive handlingen gjentas, med eller uten dødelig utgang.

Danmark er det landet hvor det har vært fokusert mest på suicidal atferd som kommunikasjon de senere år, i hvert fall forskningsmessig (Q vortrup 1999; Fleischer 2000). Både Fleischer (2000) og andre (bl.a. Jack 1992) har antydet at vi kanskje er (eller i hvert fall bør være?) i ferd med å bevege oss over fra et paradigme hvor suicidal atferd blir sett på som ren psykopatologisk atferd mot et syn der suicidale handlinger sees på som mer eller mindre normale reaksjoner på svært tøffe livspåkjenninger, eller nærmere bestemt som mer eller mindre normal kommunikasjon under uholdbare eller unormale forhold.

Q vortrup (1999) sier for eksempel:

"Suicidal atfærd er altid andet og mere end et (...) fænomen forårsaget af sygdom i sindet eller i samfundet." $\mathrm{H}$ an sier videre at atferden ofte har intensjonell betydning for den som utfører den, og at den alltid har betydning for den som den suicidale handling er rettet mot eller observeres av, fordi man alltid vil tillegge et annet menneskes atferd betydning. D et vil si at suicidal atferd ikke kan forstås som et enten-eller-fenomen, men må sees som både-og, og dermed også omfatter dynamikken de involverte instanser imellom.

$M$ ed dette som utgangspunkt har flere i de senere år argumentert for nødvendigheten av å studere suicidal atferd innenfor rammene av kommunikasjonsteori (Q vortrup 1999; Fleischer 2000; Lester 2001). På denne bakgrunn vil vi her presentere noen resultater fra vår egen forskning på dette området. D enne forskningen er gjort innenfor rammene av W HO/

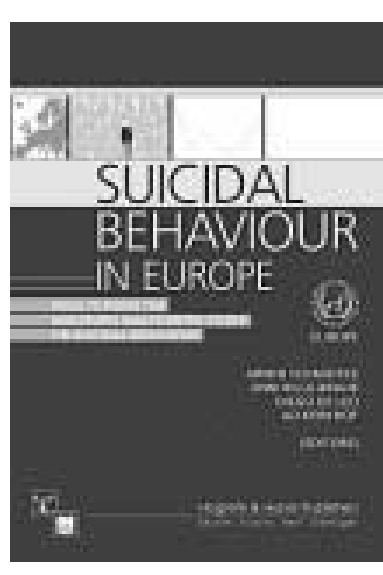
EU RO M ulticentre Study on Suicidal Behaviour (Bille-Brahe et al. 1995). Vi har undersøkt det kommunikative aspektet ved suicidale handlinger ved å ta utgangspunkt i intensjonaliteten knyttet til disse handlingene, og vi har kun fokusert på suicidale handlinger som ikke ender med døden (heretter omtalt som villet egenskade). 
Tabell 1

\section{Intensjoner med villet egenskade slik de presenteres på et} skjema i WHO-undersøkelsen

1) Tankene mine var så uutholdelige, jeg kunne ikke holde dem ut lenger.

2) Jeg ville vise noen hvor høyt jeg elsket ham/henne.

3) Det virket som om jeg mistet kontrollen over meg selv, og jeg vet ikke hvorfor jeg gjorde det.

4) Situasjonen var så uholdbar at jeg kunne ikke tenke på noe annet alternativ.

5) Jeg ville komme bort for en stund fra en uakseptabel situasjon.

6) Jeg ville at andre skulle vite hvor desperat jeg følte meg.

7) Jeg ville dø.

8) Jeg ville ha hjelp fra noen.

9) Jeg ville vite om noen virkelig brydde seg om meg.

10) Jeg ville at noen skulle betale for måten de hadde behan dlet meg på.

11) Jeg ville få noen til å føle seg skyldig.

12) Jeg ville overtale noen til å forandre mening.

13) Jeg ville gjøre ting lettere for andre.

14) Jeg ville sove en stund.

\section{Intensjoner med villet egenskade}

Det finnes mange andre intensjoner med villete egenskader enn det å dø. Det er derfor det blir så mi svisende å omtale hele denne gruppen som selvmordsforsøkere. O fte omtales villet egenskade som et rop om hjelp. Det kan dreie seg om et ønske om midlertidig flukt fra problemer, eller vanskelige sinnstilstander, eller at man ønsker å sove ekstra lenge i håp om at problemene har løst seg selv i mellomtiden. Det kan også dreie seg om å forsøke å påvirke noen til å forandre holdning eller atferd, eller det kan være en måte å teste om andre virkelig bryr seg om en på, eller å vise hvor mye man selv bryr seg om noen.

Intervjuguiden som ble brukt i W H O undersøkelsen inneholdt, blant mye annet, et skjema med 14 påstander som gikk på dette med intensjonen med handlingen og hvor pasientene skulle angi hvorvidt disse hadde hatt stor, liten eller ingen innflytelse på dem når de skadet seg selv (Tabell 1). Vi har så satt resultatene av analysen av dette skjemaet inn i en kommunikasjonsteoretisk ramme.

Ved å se på både de verbale og nonverbale aspektene ved den villete egenskaden er det muligå øke informasjonen om intensjonaliteten. Intensjoner er ikke nødvendigvis bevisste for individet selv. De kan forandre seg over tid, og sender og mottaker av denne kommunikative handlingen kan være uenige både om budskapet og om forståel sen av slike handlinger som kommunikasjon. Det siste poenget understøttes av undersøkelser som har vist forskjeller mellom det pasienten selv sier, og det pasientens pårørende og behandlere har oppfattet som intensionaliteten i handlingen (bl.a. H awton 1982). Vi har tatt utgangspunkt $\mathrm{i}$ at villet egenskade er et "prosessfenomen" med et dialogisk kommunikativt aspekt. $\mathrm{H}$ andlingen er et resultat av en lang rekke tidligere hendelser og dialoger som har ført til en beslutning om å skade seg selv. Denne handlingen fungerer altså som en erklæring og er et bidrag til tidligere dialoger med signifikante andre. Derfor må man se på både det som skjedde før den suicidale handling og på effekten av den i en kommunikasjonsteoretisk sammenheng.

Såkalt talehandlingsteori kan være et fruktbart hjel pemiddel her (A ustin 1962, Searle 1969). Talehandlingsteori oppsto i sin tid fordi man anerkjente at tegn har en grunnleggende dialogisk struktur og dermed ikke kan forstås uten at man samtidig ser på konteksten de utveksles i.
Den danske sosiologen Lars Q vortrup (1999) har utviklet dette konseptet videre i forhold til suicidal atferd på bakgrunn av pragmatisk lingvistikk. Vi vil gi en kort presentasjon av hans teori her, og etterpå presentere resultatet av en empirisk test av denne teorien som vi har gjennomført ( $\mathrm{H}$ jelmel and et al. 2002a).

\section{Qvortrups \\ kommunikasjonsteori}

Q vortrup (1999) foreslår fire kategorier som suicidale handlinger kan inndeles $i$ med utgangspunkt i handlingens funksjon. Disse er: 1) "Emosjonell i forhold til andre", der erklæringen gjelder i forhold til det emosjonelle forholdet mellom det suicidale individet og den eller de andre som handlingen er ment å skulle si noe til. 2) "Regulativ i forhold til andre", der intensjonen er å påvirke noen.

3) "Emosjonell i forhold til seg selv", der mangel på kjærlighet til en selv er sentral, for eksempel på grunn av dårlig selvbilde eller selvaktelse, og 4) "R egulativ i forhold til seg selv", der det dreier seg om å straffe seg selv fordi personen føler at han eller hun ikke greier å leve opp til forventningene fra omgivelsene.

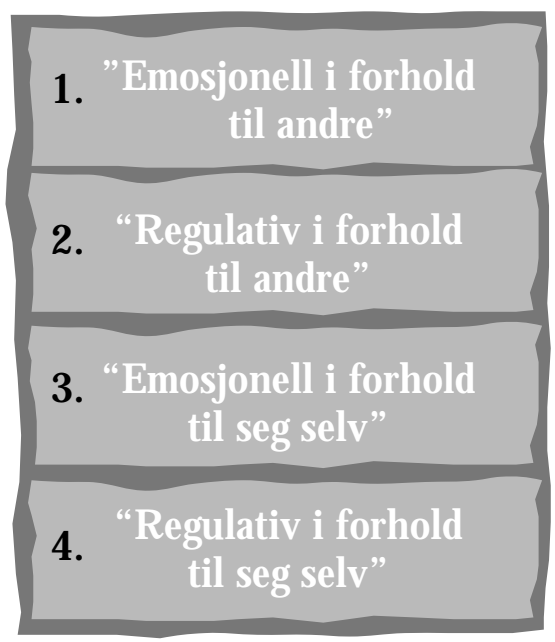

For å teste denne teorien empirisk gjorde vi en faktoranalyse av skjemaet med de 14 intensjonene fra intervjuguiden i W H O -undersøkelsen (data fra 89 norske pasienter innlagt i sykehus etter en villet egen skade, H jelmeland et al. 2002a). Resultatet viste en fire-faktorstruktur som godt kan tolkes som en støtte til Q vort- 
rups teori. Den første faktoren besto av påstander som handlet om å søke støtte og oppmerksomhet fra andre eller det å teste ut om noen var glad $i$ en (påstand 2, 6, $8 \circ \mathrm{g} 9$ 9). Vi kan godt kalle denne faktoren for "Emosjonell i forhold til andre", i tråd med Q vortrups kategori. Den andre faktoren besto av påstander som handlet om hevn, straff eller manipulasjon av andre (påstand 10, $110 \mathrm{og} 12$ ), og kan godt kalles "Regulativ i forhold til andre", for å følge $Q$ vortrup. Den tredje faktoren besto av påstander som handlet om flukt eller tap av kontroll (påstand 3, 5 og 14) og kan kalles "Emosjonell i forhold til seg selv", for å følge Q vortrups teminologi. M an kan imidlertid også tenke seg en ren deskriptiv betegnelse som for eksempel "M idlertidig flukt". Den fjerde faktoren besto av påstander som handlet om uutholdelige tanker og situasjoner, dødsintensjon og et ønske om å gjøre ting lettere for andre (påstand 1, 4, 7 og 13). Denne faktoren kan vi godt kalle "Regulativ i forhold til seg selv" for å følge Q vortrup, men her er det flere mulige fortolkninger. To av påstan dene uttrykker total resignasjon, en et eksplisitt ønske om å dø, og den siste en bekymring i forhold til andre, noe som impliserte at en selv skulle forsvinne. Et annet navn på denne faktoren kan derfor være "Endelig utgang".

Det er også mulig å se faktorene tre og fire i forhold til Engel og Schmales (1967) "giving-up - given-up"-kompleks. "G iving up" angir en tilstand av hjelpeløshet, der individet mister kontroll, autonomi og tilfredsstillelse. Faktor tre kan dermed forstås som en representasjon av denne tilstanden, og kan derfor like gjerne kalles "M idlertidig flukt". For en tilstand av "giving up" kan en forverring resultere i en "given-up"-situasjon, der en total følelse av håpløshet kontrollerer individets tanker. D ette er kan skje hva påstanden om resignasjon antyder, og kan dermed matche begrepet håpløshet, som jo ofte pekes på som den viktigste prediktoren for selvmord. N å har forskning altså vist at dette med intensjon kan ha vel så høy prediktiv verdi som håpløshet. Det vil si at intensjon kanskje er mer presis enn grunnstemningen håpløshet.
Som nevnt over kan vi konkludere med at vi fant noe empirisk støtte til Q vortrups versjon av talehandlingsteori (se H jelmeland et al. 2002a for ytterligere detaljer). Selv om kanskje spesielt den fjerde faktoren har flere fortolkningsmuligheter, er Q vortrups forslag absolutt blant dem. $\mathrm{N}$ å er det imidlertid lite sannsynlig at man har bare én intensjon med det man gjør, det være seg å skade seg selv eller andre ting. Som regel dreier det seg om flere intensjoner samtidig, selv om noen nok er mer fremtredende enn andre. Det kan derfor være mer fruktbart å se på Q vortrups teoretiske kategorier som logiske konstruksjoner, mens handlingen i seg selv må sees som en kombinasjon av de fire mulige kategoriene. Q vortrup var også inne på dette selv. I dette tilfellet vil det være bedre å forstå hans kategorier innenfor rammen av kaosteori, nemlig som fire attraktorer som definerer et dynamisk felt, der hvert individ har sin egen spesifikke posisjon avhengig av sine spesifikke omsten digheter. På denne måten kan Q vortrups modell kanskje være et nyttig hjelpemiddel i klinisk praksis når man skal finne ut av hva intensjonen med selvskadehandlingen var, altså hva vedkommende forsøkte å kommunisere ved hjelp av å skade seg selv, for så å bruke det som utgangspunkt for å finne den beste behandlingen og oppfølgingen for akkurat den pasienten eller klienten.

To viktige oppfølgingsspørsmål til dette er så om det er kjønnsforskjeller og kulturelle forskjeller her. M ed andre ord: Kommuniserer kvinner og menn forskjellige ting ved å skade seg selv? O g: Er det kulturelle forskjeller i hva som kommuniseres på denne måten?

\section{Betydningen av kjønn}

Siden midten av 1970-tallet har det vært rettet en generell oppmerksomhet mot kjønnsforskjeller i verbal kommunikasjon, mens spørsmålet om mulige kjønnsforskjeller i nonverbal kommunikasjon tilsynelatende ikke har fått så mye oppmerksomhet blant forskere. D ette med kjønn har heller ikke vært spesielt vektlagt i tidligere undersøkel ser der man har sett på intensjoner i forhold til villet egenfskade. Denne mangelen på interesse for

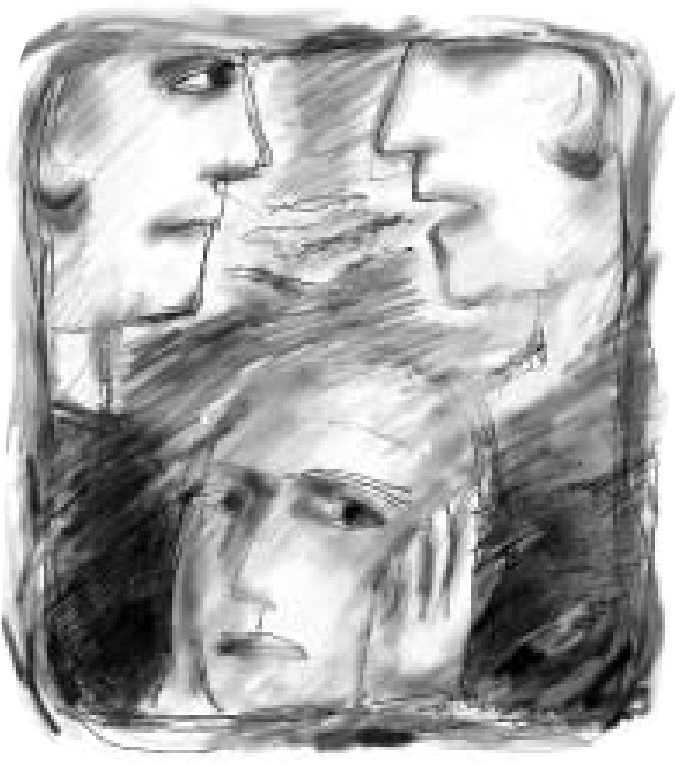

kjønn i slike studier er påfallende all den tid vi i årtier, for ikke å si århundrer, har visst at det er en kjønnsforskjell når det gjelder forekomst av suicidal atferd, i den forstand at det er flere menn enn kvinner som tar sitt eget liv, mens det er flere kvinner enn menn som skader seg selv med vilje uten å dø av det.

Vi analyserte vårt materiale med hensyn til kjønn både når det gjaldt dette med intensjoner, altså i forhold til Q vortrups fire grupper, og de variablene vi hadde tilgjengelig som sa noe om prosessen både før og etter den villete egenskaden. Det vil si noe om hvilke problemer pasientene slet med $i$ tiden før egenskaden og de reaksjonene de ble møtt med etterpå. Vi fant svært få kjønnsforskjeller, og de vi fant hadde så lav effektstørrelse at det kan hevdes at de ikke kan betraktes å ha noen særlig teoretisk eller praktisk betydning. M ed andre ord ser det ikke ut til å være noen særlig kjønnsforskjell i forhold til hva kvinner og menn kommuniserer ved hjelp av å skade seg selv. Dette er viktig å ha med når man skal tenke målrettet behandling og forebygging.

\section{Betydningen av kultur}

W $\mathrm{HO}$-undersøkelsen gir en unik mulighet til også å studere kulturelle forskjeller. 14 regioner i 13 forskjellige europeiske land har samlet data om intensjoner. Land fra både nord, sør, øst og vest $\mathrm{i}$ Europa er med. En faktoranalyse av disse 
ga en fire-faktorstruktur som var omtrent identisk med den vi fant i det norske materialet ( $\mathrm{H}$ jelmeland et al. 2002b).

$Q$ vortrups modell ser dermed ut til å kunne overføres til andre kulturer også, i hvert fall hvis vi holder oss innenfor Europa.

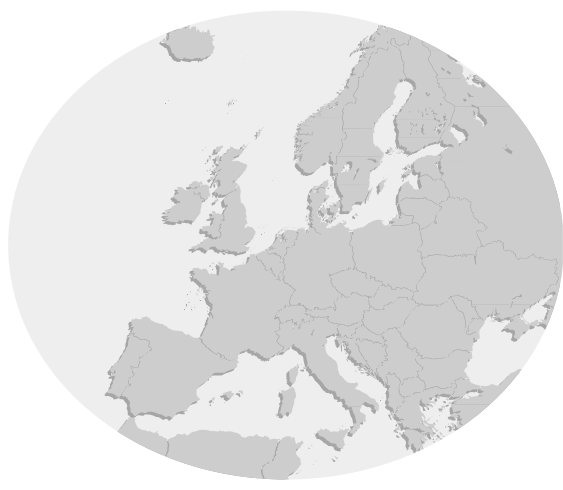

Vi fant noen statistisk signifikante forskjeller mellom regionene, men effektstørrelsene var igjen så små at det kan hevdes at disse forskjellene verken har teoretisk eller praktisk betydning (store utvalg kan gjøre selv små og ubetydelige forskjeller statistisk signifikante). Heller ikke fant vi noen særlige kjønnsforskjeller i det europeiske materialet.

Selv om det er store kulturelle forskjeller innenfor Europa, for eksempel mellom det katolske sør og det protestantiske (eller til og med mer areligiøse?) nord, er det imidlertid også mange likheter. Landene tilhører for eksempel alle den såkalt vestlige verden. $\mathrm{N}$ å er vi imidlertid i startfasen med å analysere et afrikansk materiale, og der ser det ut til å være noe annerledes enn i Europa, både når det gjelder faktorstruktur og hva som kommuniseres ved hjelp av villet egenskade. Vi kan foreløpig ikke gå nærmere inn på dette her, men slike forskjeller vil jo være av stor betydning ved behandling av innvandrere fra andre deler av verden enn vår.

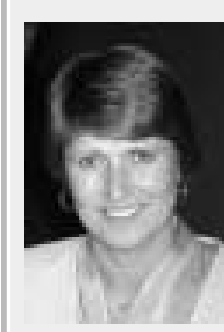

H eidi $\mathbf{H}$ jelmeland er førsteamanuensis ved Psykologisk institutt ved NT NU i Trondheim og leder for R egionalt ressurssenter for selvmordsforskning og -forebygging i M idt-N orge. $\mathrm{H}$ un er blant annet involvert $\mathrm{i}$ flere internasjonale forskningsprosjekter i suicidologi der det samles data både i europeiske og afrikanske land.

\section{Referanser}

A ustin JL. H ow to do things with words. O xford: Oxford U niversity Press, 1962

Bille-Brahe U, Schmidtke A, Kerkhof A JFM, De Leo D, Lönnqvist J, Platt S, Sampaio Faria J. B ackground and introduction to the W H O/EU RO Multicentre Study on Parasuicide. Crisis 1995; 16: 72-78+84

Engel GL, Schmale A H. Psychoanalytic theory of somatic disorder. Journal of the $A$ merican Psychoanalytic A ssociation 1967; 15(2): 344-365

Farberow N L, Shneidman ES, eds. The cry for help. N ew York: M cG raw-H ill, 1961

Fleischer E. D en talende tavshed. Selvmord og selvmordsforsøg som talehandling. 0 dense: 0 dense U niversitetsforlag, 2000.

Gilje N , G rimen H. Samfunnsvitenskapenes forutsetninger. O slo: U niversitetsforlaget, 1993

$\mathrm{H}$ awton $\mathrm{K}$. H ow patients and psychiatrists account for overdoses. I: Shepherd E, W atson JP, red.: Personal meanings. C hicester: Wiley, 1982: 103-114.

$\mathrm{H}$ jelmeland $\mathrm{H}$. Verbally expressed intentions of parasuicide: II. Prediction of fatal and nonfatal repetition. C risis 1996; 17(1): 10-14

$\mathrm{H}$ jelmeland $\mathrm{H}$, Knizek BL, N ordvik $\mathrm{H}$. T he communicative aspect of non-fatal suicidal behaviour - are there gender differences? Crisis, 2002a; 23(4) 144-155

$\mathrm{H}$ jelmeland $\mathrm{H}, \mathrm{H}$ awton $\mathrm{K}, \mathrm{N}$ ordvik $\mathrm{H}$, Bille-Brahe $U$, De Leo D, Fekete $S, G$ rad O, H aring C, Kerkhof A JFM, Lönnqvist J, Michel $K$, Salander-Renberg $E$, Schmidtke A, Van H eeringen $K$, W asserman D. W hy people engage in parasuicide: $A$ cross-cultural study of intentions. Suicide and Life-T hreatening Behavior, 2002b; 32(4): 380-393

Jack R. Women and attempted suicide. H ove: Erlbaum, 1992

Lester D. N onfatal suicidal behavior as a communication. C risis 2001; 22(2): 49-51

Q vortrup L. Selvmordsadfærd, kommunikation og sprog - teoretiske perspektiver. I Beskow J, Eriksson $B E, N$ ikku N, red. Självmordsbeteen de som språk. Stockholm: Forskningsrådsnämden, 1999: 13-36

Retterstøl N, Ekeberg $\varnothing$, M ehlum L, red. Selvmord - et personlig og samfunnsmessig problem.

O slo: U niversitetsforlaget, 2002

Searle JR. Speech A cts. A n essay in the philosophy of language. $C$ ambridge: $C$ ambridge U niversity Press, 1969

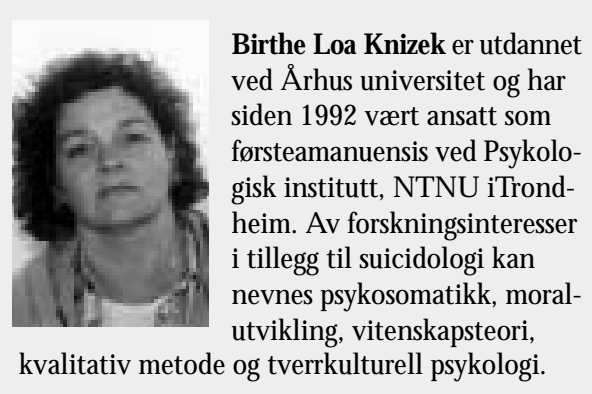

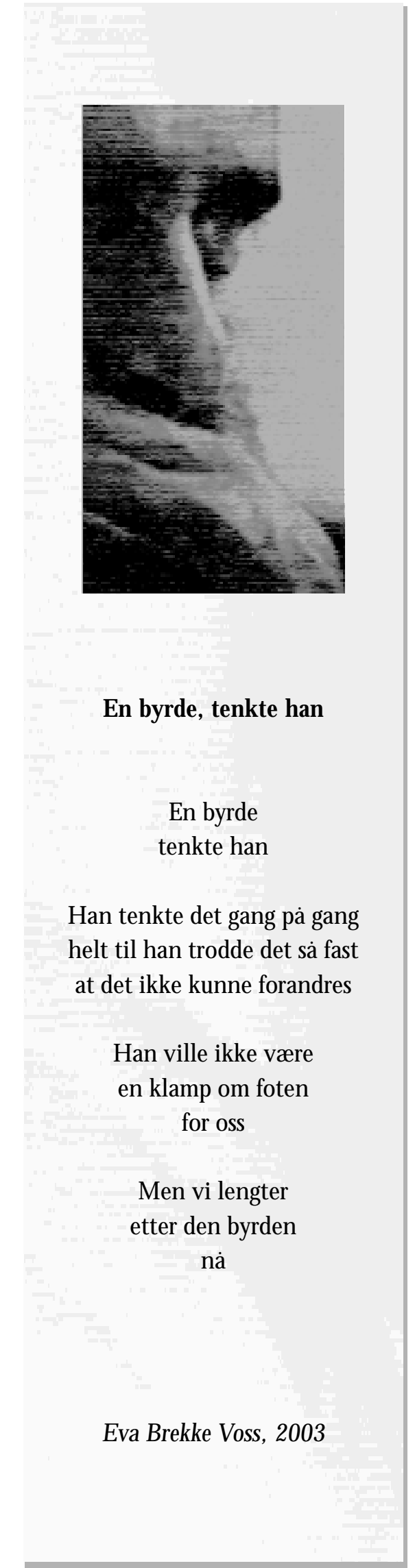

